\title{
Correction to: Structural analysis and developmental stages of domatia of Schinus terebinthifolius Raddi (Anacardiaceae)
}

Saulo Pireda ${ }^{1}$ Jonas de Brito Campolina Marques $^{1} \cdot$ Guilherme Rodrigues Rabelo $^{1}$. Maura Da Cunha ${ }^{1}$

Published online: 27 October 2017

(c) Botanical Society of Sao Paulo 2017

\section{Correction to: Braz. J. Bot}

\section{DOI 10.1007/s40415-017-0414-z}

The panels in Figs. 1-34 were incorrectly labelled in the initial online publication. The original article has been corrected.

The online version of the original article can be found under doi:10.1007/s40415-017-0414-z.

Maura Da Cunha

maurauenf@gmail.com

1 Centro de Biociências e Biotecnologia, Laboratório de Biologia Celular e Tecidual, Setor de Biologia Vegetal, Universidade Estadual do Norte Fluminense Darcy Ribeiro, Avenida Alberto Lamego, 2000, Campos dos Goytacazes, Rio de Janeiro 28013-602, Brazil 